\title{
MORPHOMETRIC CHARACTERISTICS OF INFLORESCENCES AND PHENOLOGY OF INTRODUCED PLANTS OF THE GENUS CRATAEGUS L. IN THE KOLA SUBARCTIC CONDITIONS
}

(C) 2019

Zotova Olesya Evgenievna, junior researcher of Plant Introduction and Acclimatization Laboratory

Goncharova Oksana Aleksandrovna, candidate of biological sciences,

senior researcher of Plant Introduction and Acclimatization Laboratory

N.A. Avrorin Polar-Alpine Botanical Garden-Institute of Kola Scientific Centre of Russian Academy of Sciences

(Apatity, Murmansk Region, Russian Federation)

Abstract. This paper presents phenological development of seven introduced species of the genus Crataegus L. in the Kola North. The studied hawthorn species are characterized by early onset of vegetation, short duration of linear growth of shoots and a short vegetation period. Timely completion of growth processes and lignification of shoots contribute to successful adaptation of Crataegus plants under the conditions of introduction. The authors study morphometric parameters of flowers and inflorescences, decorative qualities, size and density of the inflorescence, the number of flowers in the inflorescence, the diameter of the flowers. The most decorative species of Crataegus during flowering are selected. The plants of the studied hawthorns are characterized by the average duration of the prefloral period, annual / irregular flowering. The most decorative species during flowering are the ones with larger flowers and inflorescences: C. maximoviczii and C. dahurica. Species with a large number of flowers are characterized by a denser inflorescence. Species with smaller flowers form smaller inflorescences and vice versa. In the conditions of the Kola Subarctic, the number of flowers in the inflorescence depends mainly on the specific features. C. maximoviczii is recommended for gardening in northern cities.

Keywords: ecological factors; ecological conditions; introduction; phenological development; phenological phases; duration of vegetation; woody plants; Rosaceae Juss. family - Rosaceous; genus Crataegus L. - hawthorn; prefloral period; duration of bloom; bloom; number of flowers; inflorescence; size of inflorescences; density of inflorescences; Kola Subarctic.

$* * *$

УДК $57.042 ; 577.3$

DOI 10.24411/2309-4370-2019-13107

Статья поступила в редакцию 10.06.2019

\section{ACER PLATANOIDES L. В УСЛОВИЯХ АНТРОПОГЕННОЙ НАГРУЗКИ Г. ДОНЕЦКА}

(C) 2019

Корниенко Владимир Олегович, старший преподаватель кафедры биофизики

Кольченко Ольга Руслановна, магистрант кафедры биофизики

Донецкий национальный университет (г. Донецк, Донецєкая Народная Республика)

Матвеева Татьяна Борисовна, кандидат биологических наук, доцент кафедры биологии, экологии и методики обучения

Самарский государственный соџиально-педагогический университет (г. Самара, Российская Федерация)

Аннотащия. В данной статье представлена не описанная ранее в условиях города Донецка экологобиологическая характеристика клена остролистного (Acer platanoides L.). Описывается городская среда как уроэкосистема и трансформации в ней под воздействием антропогенных факторов. Рассматривается влияние антропогенной среды в городе на растительные организмы, а также физиологические и морфологические изменения в них. В ходе проведенных исследований определен высокий уровень антропогенной нагрузки в городе Донецке на основе анализа показателей вибрационно-акустического шума вдоль автомагистралей, концентрации тяжелых металлов в почвах и концентрации аэрополлютантов в атмосферном воздухе на исследуемых участках. Установлена тесная связь показателя флуктуирующей асимметрии листовых пластин клена остролистного с показателем жизнеспособности и уровнем шумового загрязнения вдоль автомагистралей. Изучены основные параметры механической устойчивости Acer platanoides L. в г. Донецке в условиях техногенной нагрузки и в зоне контроля (дендрарий Донецкого ботанического сада). Установлено, что наибольшему риску облома подвержены молодые деревья (5-7 лет) и деревья, имеющие низкий балл жизнеспособности вследствие приближения критического возраста в условиях города. Полученные результаты могут быть использованы при биомониторинговых исследованиях состояния окружающей городской среды.

Ключевые слова: Acer platanoides L.; антропогенная нагрузка; тяжелые металлы; аэрополлютанты; вибрационно-акустический шум; механическая устойчивость; жесткость на изгиб; флуктуирующая асимметрия; жизнеспособность; город Донецк; Донецкий ботанический сад; биомониторинг; биоиндикация; городская среда; древесные растения.

\section{Введение}

Город на современном этапе - это природноантропогенная система, основными системообразующими факторами которой являются человек и природная среда $[1$, с. 9]. В этой системе имеется большое количество антропогенных фактов. Поэтому очень трудно выделить влияние одного фактора на живые организмы в отрыве от остальных. Городская среда активно аккумулирует и накапливает загрязняющие вещества и отходы, засоряя при этом атмосферу, водоемы и почвы [2, с. 129]. В центральных частях города часто отмечается превышение пре- 
Корниенко В.О., Кольченко О.Р., Матвеева Т.Б.

дельно допустимой концентрации (ПДК) различных микроэлементов и тяжелых металлов в почвах. В атмосферном воздухе увеличивается концентрация дыма, пыли, копоти, токсичных газов и патогенной микрофлоры [3, с. 191]. По данным 2010 года в г. Донецке на долю выхлопных газов приходилось $26,7 \%$, от общего числа вредных веществ [4, с. 7]. Валовый же объем выбросов выхлопных газов в 2003 г. составил 205,4 тыс. т [5, с. 75].

В центральных частях города наблюдается повышенный уровень вибрационно-акустического шума. По данным многочисленных экологических исследований, шум - один из серьезных факторов загрязнения окружающей среды [6, с. 63]. Городской шум имеет тенденцию быстрого роста. По данным А.В. Васильева [7, с. 158], уровень шума в городах возрастает ежегодно на 0,5-1,0 дБА. Шумовое воздействие имеет преимущественно локальный характер и вызывается транспортными средствами в $80 \%$ случаев [8, с. 169].

Растительные организмы, в особенности древесные растения, в крупных городах произрастают в специфической экологической городской среде и постоянно подвергаются воздействию комплекса антропогенных факторов [9, с. 95]. Под воздействием негативных факторов у растительных организмов наблюдается преждевременное старение, общее ослабление организма, что приводит к неспособности бороться с болезнями, снижается продуктивность $[10$, c. 59]. Высокая устойчивость растений к антропогенным условиям определяется их способностью к изменению физиологических процессов и приспособленности к экстремальным факторам. В целом, устойчивость растений зависит от факторов внешней среды, а также от состояния самого растения и его индивидуальных особенностей [11, с. 88].

В городской среде часто можно наблюдать, что деревья имеют редкую крону, с большой долей сухобочинности или суховершинности. Такую картину часто можно наблюдать в ряду деревьев, высаженных вблизи автомагистралей с высокой интенсивностью автотранспортного потока. У растений, произрастающих возле полотна дороги, уменьшается средний диаметр и высота, больше процент усохших ветвей в кронах и меньшая степень облиственелости крон. Эти показатели свидетельствуют о худших экологических условиях для произрастания древесных растений [12, с. 29]. В городских условиях чаще наблюдаются такие нарушения, как кривизна ствола, механические повреждения ветвей, сухобочинность, обдир коры, морозные трещины и искривления. Трещины и раны чаще возникают из-за нарушения деятельности камбия. При появлении трещин и ран появляется большая вероятность проникновения множества вредителей и патогенных микроорганизмов, вследствие чего может развиться рак дерева, а в дальнейшем и его гибель.

Листовая пластина является самым чувствительным и информативным органом растительного организма, поэтому его параметры достаточно часто используют для биоиндикации загрязнения окружающей среды. У растений, которые аккумулируют загрязняющие вещества, нарушается развитие листовых пластин [5, с. 75]. Наиболее ярким признаком воздействия загрязняющих веществ на ассимиляционный аппарат является уменьшение площади листовой пластины.

В условиях городской среды, в особенности в центральных частях города около автотранспортных магистралей, период вегетации у древесных расте- ний начинается на 3-5 дней раньше, чем у деревьев в естественной среде обитания и даже у тех деревьев, которые произрастают в парковых зонах. Вследствие этого наблюдается уменьшение площади, длины и ширины листовых пластин на 7\%.

При высокой антропогенной нагрузке наблюдается также явление асимметрии и разнообразных геометрических нарушений листовых пластинок. На данный момент изучение флуктуирующей асимметрии листовых пластин древесных растений является актуальным методом биоиндикации состояния окружающей среды и показателем стабильности развития самого организма. Говоря о влиянии антропогенной нагрузки на ассимиляционный аппарат, Жуковым было показано, что увеличение уровня данной нагрузки сопровождается уменьшением формотипического разнообразия листовой пластинки Betula pendula Roth [13, с. 128].

Цель работы: представить эколого-биологическую характеристику Acer platanolides L. в условиях антропогенной нагрузки г. Донецка.

\section{Материалы и методы исследования}

Карта местности и участков, на которых проводились исследования, представлена на рисунке 1.

Исследования проводились на пяти участках г. Донецка, находящихся в Калининском и Будёновском районах. На территории дендрария Донецкого ботанического сада исследования проводились на участке произрастания куртин (групп растений) Acer platanoides $\mathrm{L}$.

По Макеевскому шоссе деревья произрастают в один ряд, удаленный от дорожного полотна на 3 м. По пр. Ильича исследуемые деревья растут в 2 ряда с расстоянием 3,5 м. От дороги первый ряд располагается на расстоянии 3-х метров. Дорожное полотно разделено: 1) бордюром, 2) асфальтированной пешеходной дорогой $(1 \mathrm{M}), 3)$ небольшим бордюром, отделяющим земляной покров от асфальтированного участка. По ул. Светлого Пути исследуемые объекты произрастают в один ряд на расстоянии 3,5 м от дорожного полотна. По ул. Крепильщиков деревья растут на расстоянии 2 м от дороги.

На исследуемых участках проводили измерения шума и интенсивности движения автотранспорта.

Разделение исследуемых участков на блоки по пр. Ильича и Макеевскому шоссе показано на рис. 2 и рис. 3.

Клен остролистный (Acer platanoides L.) - широко распространенный в Европе и юго-западной Азии вид. Произрастает в лиственных и смешанных лесах, один из эдификаторов широколиственных лесов. Крона овальная, у взрослых деревьев в одиночных посадках раскидистая, плотная. Древесина отличается прочностью и упругостью, что дает возможность роста ветвей в горизонтальном направлении и захвата пространства вокруг ствола. В чистых насаждениях создает сильный затеняющий эффект, предотвращая развитие растительности нижних ярусов. Теневыносливы только молодые деревья. Дерево очень декоративно кроной и листвой, применяется в одиночных, групповых, аллейных насаждениях [14, с. 39]. Клен остролистный в целом устойчив к вредителям, однако часто поражается грибами (ритисмой кленовой), вызывающими пятнистость листьев. Также данный вид древесных растений не подвергается гибридизации с другими видами рода Acer, имеет ярко выраженные видовые признаки, что помогает легко его отличить от других представителей рода. 


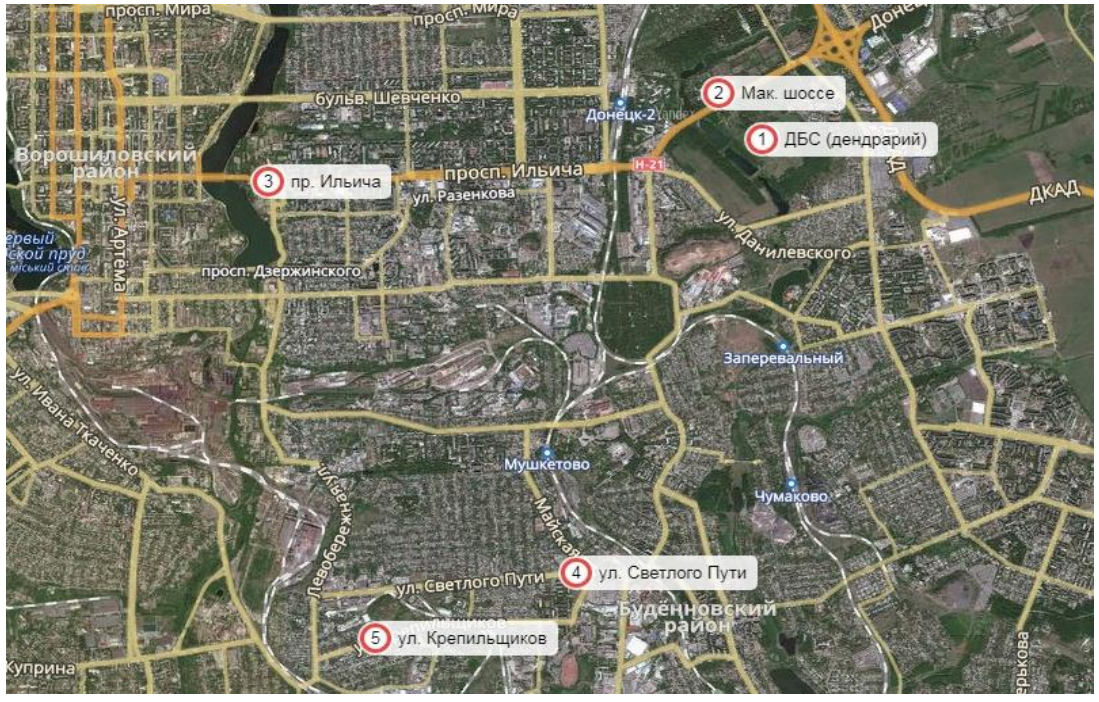

Рисунок 1 - Карта исследуемых участков

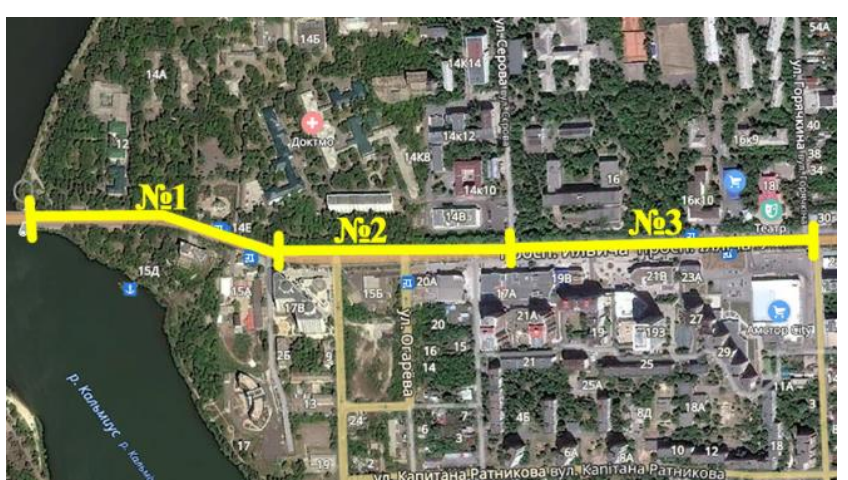

Рисунок 2 - Участки измерения шума и интенсивности автотранспортного потока по пр. Ильича:

№ 1 - от р. Кальмиус (мост) до ост. Больница им. Калинина; № 2 - от ост. Больница им. Калинина до ул. Серова; № 3 - от ул. Серова до ул. Горячкина

Мониторинг содержания токсических веществ в воздухе и почвах проводили в период с 2017 по 2018 гг. Для забора воздуха вблизи автомагистралей пользовались универсальным газоанализатором ГАНК-4. Содержание оксида азота, диоксида азота, оксида углерода, хлора, аммиака и сульфида водорода в атмосферном воздухе определяли согласно руководству РД 52.04.186-89 [15, с. 23-24].

Исследование содержания тяжелых металлов $(\mathrm{Cu}$, $\mathrm{Zn}, \mathrm{Cd}, \mathrm{Ni}, \mathrm{Mn}, \mathrm{Co}, \mathrm{Cr}$ ) в почве проводили на атомноабсорбционном спектрофотометре (ААС). Отбор проб и дальнейшее исследование проводили по ГОСТ [16, с. 3-4]. Оценку результатов проводили согласно регламентирующим ПДК.

Исследование вибрационно-акустического шума вдоль автомагистралей проводили с помощью измерителя уровня шума GM1351 и портативного осциллографа. Измерение шума производилось через каждые 30-40 метров возле автотрассы, 1 ряда и 2 ряда.

Для оценки морфометрических параметров листовых пластин исследовали показатель флуктуирующей асимметрии. Листья были собраны в середине-конце августа. С каждого дерева было собрано по 5-10 листьев с нижней световой части кроны. Все измерения проводились в программе Axio Vision ver. 4.8. Для определения показателя флуктуирующей асимметрии проводили измерения четырех парамет-

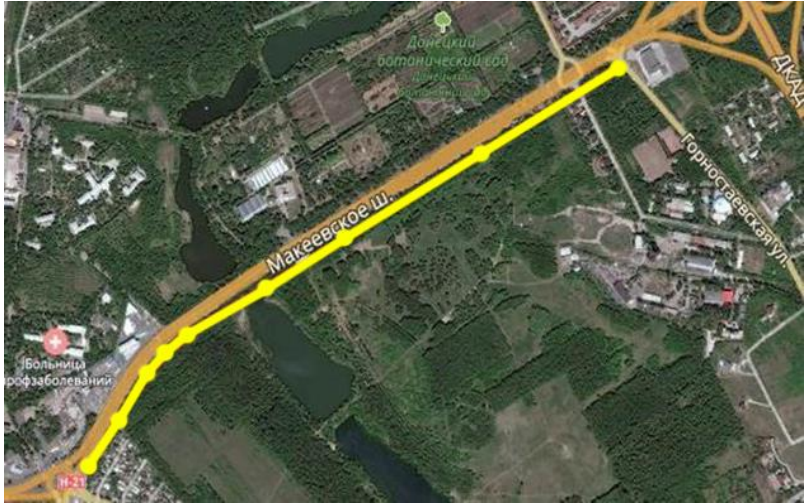

Рисунок 3 - Участок измерения уровня шума и интенсивности автотранспортного движения по Макеевскому шоссе от ост. Мотель до ул. Горностаевская

ров листовой пластины с левой и с правой стороны [9, с. 96]. Жизнеспособность исследованных деревьев определяли по 8-балльной шкале С.А. Савельевой [17, с. 19].

Для оценки прочности и механической устойчивости древесных растений в урбанизированных городах использовали следующие параметры:

$P_{c r}$ и $m_{c r}-$ предельно допустимая нагрузка и масca, при действии которых ствол начинает деформироваться или обламывается [18, с. 1592]:

$$
\begin{gathered}
P C r=\frac{\pi^{2} E I}{2 l^{2}} \\
m c r=\frac{P C r}{g}
\end{gathered}
$$

где $I$ - момент инерции сечения, $l$ - длина ствола, $g-$ ускорение силы тяжести.

$H_{c r}$ - критическая высота ствола, при достижении которой действие собственного веса привело бы к необратимой деформации или облому [19, с. 58]:

$$
\mathrm{Hcr}=\mathrm{c} \cdot \frac{E^{1 / 3}}{\rho} \cdot d^{2 / 3}
$$

где $C$ - коэффициент соотношения массы кроны и ствола, $d$ - диаметр основания ствола. 
Корниенко В.О., Кольченко О.Р., Матвеева Т.Б.

$R R B$ - относительное сопротивление изгибу $[18$, c. 1593]:

$$
R R B=\frac{r^{2} E}{4 \rho}
$$

где $r$ - радиус основания ствола, $E$ - модуль упругости, $\rho$ - плотность древесины.

Для статистической обработки данных использовали программы «Statistica 8» (StatSoftInc.) и «Excel 2010» (Microsoft Corporation). Достоверность отличий средних значений полученных данных определяли с использованием t-критерия Стьюдента. Коэффициент вариации вычисляли согласно рекомендациям Лакина [20, с. 228]. Для описания зависимостей использовали методы регрессионного анализа.

\section{Результаты и обсуждения}

На исследуемых участках была рассчитана интенсивность автотранспортного движения в качестве оценки загруженности автомагистралей (табл. 1). Выявлено, что наиболее загруженными являются участки по пр. Ильича (в среднем 1333 ед./час) и Макеевскому шоссе (902 ед./час). При этом показано, что преобладающим видом транспорта на участках по пр. Ильича является пассажирский легковой автотранспорт, преимущественно автомобили иностранного производства (в среднем 1000 ед./час). Преобладающим видом транспорта на участке Макеевского шоссе являются грузовые автомобили и легковые иномарки. По ул. Светлого пути наблюдалось прохождение 612 ед./час, среди которых в основном преобладали легковые иномарки и легковые отечественного производства. Наименее загруженным участком является ул. Крепильщиков с интенсивностью движения 27 ед./час.

Таблица 1 - Интенсивность движения автотранспорта на исследуемых участках г. Донецка, ед./час

\begin{tabular}{|c|c|c|c|c|c|c|c|}
\hline \multirow{3}{*}{$\begin{array}{l}\text { Уча- } \\
\text { сток }\end{array}$} & \multicolumn{7}{|c|}{ Вид автотранспорта } \\
\hline & \multicolumn{2}{|c|}{ Грузовые } & \multicolumn{3}{|c|}{$\begin{array}{c}\text { Пассажирские } \\
\text { легковые }\end{array}$} & \multicolumn{2}{|c|}{$\begin{array}{l}\text { Муниципаль- } \\
\text { ный транспорт }\end{array}$} \\
\hline & $\begin{array}{l}\text { Тяже- } \\
\text { лые }\end{array}$ & $\begin{array}{l}\text { Лег- } \\
\text { кие }\end{array}$ & $\mathrm{a}$ & 6 & B & $\begin{array}{l}\text { Авто- } \\
\text { бус }\end{array}$ & $\begin{array}{l}\text { Трол- } \\
\text { лейбус }\end{array}$ \\
\hline 1 & 96 & 48 & 324 & 108 & 24 & 12 & - \\
\hline 2 & $<1$ & 5 & 10 & 7 & $<1$ & 3 & - \\
\hline 3 & $<1$ & 72 & 1008 & 96 & 96 & 59 & 6 \\
\hline 4 & $<1$ & 79 & 989 & 98 & 94 & 59 & 6 \\
\hline 5 & $<1$ & 73 & 1005 & 101 & 92 & 59 & 6 \\
\hline 6 & 120 & 108 & 468 & 84 & 84 & 35 & 3 \\
\hline
\end{tabular}

Примечание. $a$ - иномарки легковые; $\sigma$ - легковые отечественные BA3, Lanos и т.д.; в - иномарка внедорожник; участки: 1 - ул. Светлого Пути; 2 - ул. Крепильщиков; 3 - пр. Ильича от р. Кальмиус (мост) до остановки больница им. Калинина; 4 - пр. Ильича от остановки больница им. Калинина до ул. Серова; 5 - пр. Ильича ул. Серова до ул. Горячкина; 6 - Макеевское шоссе (остановка Мотель) до ул. Горностаевская.

На участках с наиболее высокими показателями интенсивности автотранспортного потока были превышены значения акустического шума (табл. 2). На исследуемых нами участках возле дорог максимальные показатели по уровню шума в среднем были $87 \pm 3$ дБА. По средним арифметическим показате- лям уровень акустического шума был в пределах $78 \pm 2$ дБА. При удалении от дороги к первому ряду произрастающих деревьев было замечено уменьшение уровня звукового давления по максимальным значениям до $80 \pm 4$ дБА, что говорит о том, что древесные насаждения первого ряда берут на себя значительную антропогенную нагрузку, исходящую от автомагистрали.

Таблица 2 - Значения акустического шума на исследуемых участках города Донецка, дБА

\begin{tabular}{|c|c|c|c|c|c|c|}
\hline \multirow{2}{*}{$\begin{array}{c}\text { Уча- } \\
\text { сток }\end{array}$} & \multicolumn{2}{|c|}{$\begin{array}{c}\text { Возле дороги } \\
\text { (бордюр) }\end{array}$} & \multicolumn{2}{c|}{$\begin{array}{c}1 \text { ряд } \\
\text { деревьев }\end{array}$} & \multicolumn{2}{c|}{$\begin{array}{c}2 \text { ряд } \\
\text { деревьев }\end{array}$} \\
\cline { 2 - 7 } & $\max$ & $\bar{X} \pm S_{x}$ & $\max$ & $\bar{X} \pm S_{x}$ & $\max$ & $\bar{X} \pm S_{x}$ \\
\hline 1 & 93 & $79 \pm 4$ & 88 & $78 \pm 4$ & - & - \\
\hline 2 & 86 & $75 \pm 3$ & 76 & $73 \pm 3$ & - & - \\
\hline 3 & 85 & $79 \pm 3$ & 81 & $73 \pm 3$ & 74 & $69 \pm 2$ \\
\hline 4 & 88 & $78 \pm 3$ & 80 & $74 \pm 3$ & 73 & $68 \pm 2$ \\
\hline 5 & 86 & $80 \pm 3$ & 77 & $73 \pm 3$ & 73 & $68 \pm 2$ \\
\hline 6 & 84 & $75 \pm 3$ & 78 & $75 \pm 3$ & 72 & $69 \pm 2$ \\
\hline Д* & \multicolumn{5}{|c|}{$45 \pm 5$} \\
\hline
\end{tabular}

Примечание. Д* - дендрарий Донецкого ботанического сада (ДБС), естественный шум в насаждениях клена остролистного; участки: 1 - ул. Светлого Пути; 2 - ул. Крепильщиков; 3 - пр. Ильича от p. Кальмиус (мост) до остановки больница им. Калинина; 4 - пр. Ильича от остановки больница им. Калинина до ул. Серова; 5 - пр. Ильича ул. Серова до ул. Горячкина; 6 - Макеевское шоссе (остановка Мотель) до ул. Горностаевская; $\bar{X} \pm S_{x}$ - среднее значение \pm стандартное отклонение.

Уровень интенсивности транспортного потока вносит изменения в состав почв. Это отражается на концентрации тяжелых металлов в почвах близ автомагистралей. Вследствие повышения концентрации тяжелых металлов в почвах, увеличивается риск токсического воздействия на растения. Концентрации тяжелых металлов для почв вдоль магистралей на исследуемых участках показаны в таблице 3 .

Исследования атмосферного воздуха показали, что концентрации большинства исследуемых веществ были в пределах ПДК. Обнаружены превышения концентраций сероводорода практически на всех участках, концентрации угарного газа были у верхней границы ПДК, а также обнаружены показатели по аммиаку.

Анализируя полученные данные, можно сказать, что имеются превышения уровня акустического шума по сравнению с таковыми ПДУ на территории Макеевского шоссе и по ул. Крепильщиков в 1,2 раза. Чуть меньшее превышение (в 1,1 раза) наблюдается по пр. Ильича и ул. Крепильщиков.

Наибольшая концентрация меди обнаружена в почвах на территориях ул. Светлого Пути (в 38 раз) и по пр. Ильича в первом ряду произрастания зеленых насаждений (в 14 раз). На этих же территориях имеются большие превышения показателей концентрации цинка в 2,2 раза и в 1,4 раза соответственно. В почвах второго ряда по пр. Ильича и по ул. Крепильщиков превышены концентрации меди в 9 раз, а в почвах вдоль Макеевского шоссе в 4 раза. Также на территории Макеевского шоссе имеется превышение по содержанию цинка в 1,7 раз. На ул. Крепильщиков обнаружено превышение содержания хрома в 4 раза, чего не наблюдалось на всех остальных исследуемых территориях. 
Корниенко В.О., Кольченко О.Р., Матвеева Т.Б.

Acer platanoides L. в условиях антропогенной нагрузки г. Донецка

Общая биология

Таблица 3 - Показатели концентрации тяжелых металлов в почвах на исследуемых участках

\begin{tabular}{|c|c|c|c|c|c|c|c|}
\hline Участок & Со & $\mathrm{Mn}$ & $\mathrm{Cd}$ & $\mathrm{Cr}$ & $\mathrm{Ni}$ & $\mathrm{Zn}$ & $\mathrm{Cu}$ \\
\hline Контроль (ДБС) & н/o & $63 \pm 5$ & $0,04 \pm 0,01$ & $0,2 \pm 0,01$ & $0,08 \pm 0,01$ & н/o & $0,005 \pm 0,001$ \\
\hline 1 & $0,4 \pm 0,2$ & $135 \pm 12$ & $0,05 \pm 0,01$ & $2,5 \pm 0,21$ & $0,45 \pm 0,03$ & $50,0 \pm 5$ & $115,0 \pm 12,5$ \\
\hline 2 & $0,5 \pm 0,1$ & $122 \pm 14$ & $0,01 \pm 0,002$ & $13,0 \pm 1,1$ & $0,60 \pm 0,05$ & H/o & $27,5 \pm 3,1$ \\
\hline 3 & $0,1 \pm 0,01$ & $114 \pm 9$ & $0,1 \pm 0,01$ & $1,0 \pm 0,1$ & $0,12 \pm 0,03$ & $33,0 \pm 3$ & $42,5 \pm 4,4$ \\
\hline 4 & н/o & $64 \pm 7$ & $0,1 \pm 0,03$ & $0,5 \pm 0,03$ & $0,17 \pm 0,04$ & $5,0 \pm 1,1$ & $27,0 \pm 3,3$ \\
\hline 5 & $0,1 \pm 0,03$ & $68 \pm 7$ & $0,1 \pm 0,02$ & $0,8 \pm 0,05$ & $0,17 \pm 0,03$ & $39,0 \pm 3$ & $12,0 \pm 1,3$ \\
\hline ПДК & п.ф. & вал. & вал. & п.ф. & п.ф. & п.ф. & п.ф. \\
& 5,0 & 1500,0 & 1,5 & 6,0 & 4,0 & 23,0 & 3,0 \\
\hline
\end{tabular}

Примечание. 1 - ул. Светлого Пути; 2 - ул. Крепильщиков; 3 - пр. Ильича 1 ряд насаждений; 4 - пр. Ильича, 2-й ряд насаждений; 5 - Макеевское шоссе (остановка Мотель) до ул. Горностаевская; $n . \phi$. - подвижная форма; вал. - валовая форма.

Практически на всех исследуемых территориях, кроме дендрария Донецкого ботанического сада и ул. Крепильщиков, обнаружено превышение содержания сероводорода в атмосферном воздухе в 2,53 раза. Концентрации угарного газа и аммиака ПДК не превышают, но находятся на верхней границе допустимой нормы, что, по нашему мнению, может оказывать влияние на растительные организмы.

Связывая жизнеспособность растительных объектов с показателями флуктуирующей асимметрии их листовых пластин, наблюдаем зависимость между этими двумя параметрами (рис. 4). Высокий показатель флуктуирующей асимметрии свидетельствует о низкой жизнеспособности древесного растения. Таким образом, по данным флуктуирующей асимметрии можно оценить жизнеспособность всего растительного организма клена остролистного (по результатам исследований).

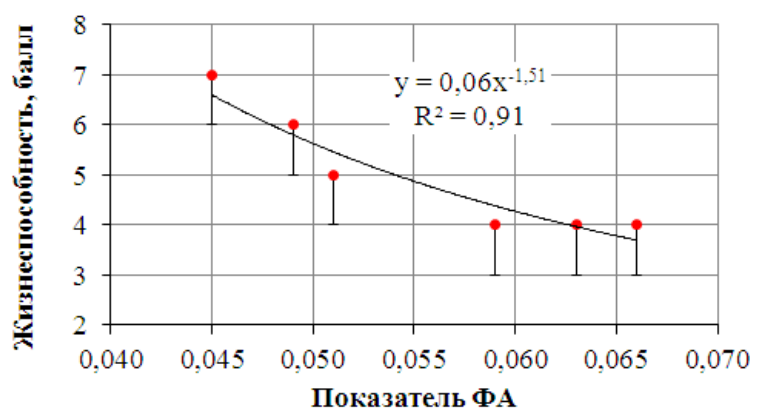

Рисунок 4 - Зависимость степени

флуктуирующей асимметрии от жизнеспособности клена остролистного в условиях города Донецка

Также прослеживается зависимость показателя флуктуирующей асимметрии от уровня шума, исходящего от автомагистрали на исследуемых территориях (рис. 5). Таким образом, при повышении уровня шума наблюдается увеличение показателя флуктуирующей асимметрии.

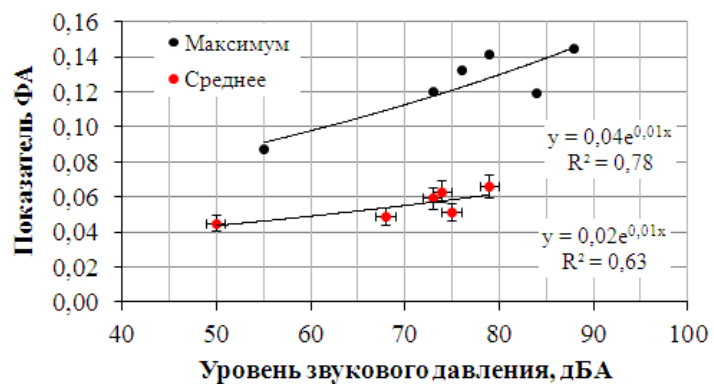

Рисунок 5 - Зависимость показателя флуктуирующей асимметрии от уровня шума вдоль автомагистралей города Донецка
Можно заключить, что при повышенном уровне зашумленности автомагистралей, в особенности превышающем ПДУ, снижается жизнеспособность всего растительного организма, произрастающего на зашумленной территории.

Благодаря механическим свойствам древесины и развитой корневой системе дерево обладает высокой устойчивостью к ветрам и другим механическим нагрузкам (рис. 6). В период вегетации листья создают значительный парусный эффект, поэтому в случае сильных ветров, особенно в засушливый период, есть риск облома ветвей.

Меры по увеличению механической устойчивости: санитарная обрезка, зауживание кроны (укорачивание длинных горизонтальных ветвей), полив в период засухи. Произрастая вдоль транспортного полотна, при надлежащем уходе, в засушливый период порода устойчива к комплексному воздействию транспортного потока и пригодна для посадки в первом ряду вдоль дорог.

\section{Bыводы}

В результате проведенных исследований был выявлен высокий уровень антропогенной нагрузки на деревья клена остролистного, произрастающего вдоль автомобильных магистралей города Донецка. Уровень звукового давления превышен в среднем на 10-14\%. Содержание Zn в почвах вдоль автомагистралей превышено в среднем в 1,8 раза, $\mathrm{Cu}-$ в 16 раз. Для $\mathrm{Cr}$ превышение составило в 2 раза от ПДК, но только на одном участке (ул. Крепильщиков). Исследования на содержание токсических веществ в воздухе показали превышение ПДК только по $\mathrm{H}_{2} \mathrm{~S}$ (сероводород), в среднем в 2,2 раза. По высоким показателям флуктуирующей асимметрии можно судить о чувствительности листового аппарата клена остролистного, что дает возможность использования данного вида древесных растений в качестве биоиндикатора. Вследствие воздействия антропогенной нагрузки наблюдается снижение жизнеспособности Acer platanoides L. Установлена тесная связь показателя флуктуирующей асимметрии с показателем жизнеспособности $\left(\mathrm{R}^{2}=0,91\right)$ и уровнем шумового загрязнения $\left(\mathrm{R}^{2}=0,7\right)$. По результатам исследований Acer platanoides L. является механически устойчивой породой в условиях г. Донецка. Для повышения механической устойчивости рекомендуется производить санитарную обрезку с целью зауживания кроны (укорачивание длинных горизонтальных ветвей). В целом приходим к выводу, что, произрастая вдоль автомагистралей, при надлежащем уходе, вид устойчив к комплексному воздействию транспортного потока и пригоден для посадки в первом ряду вдоль дорог. 


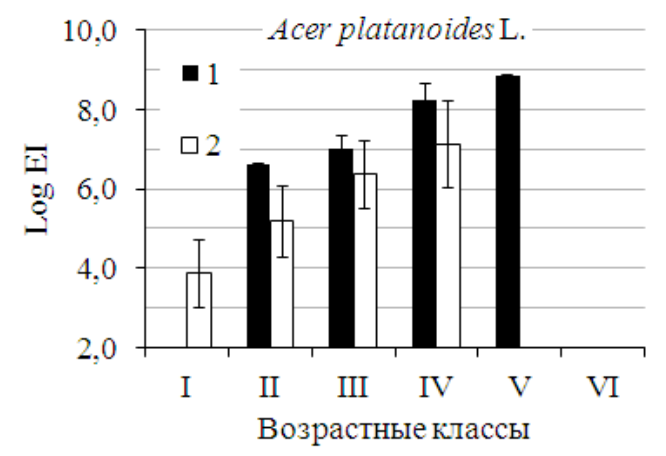

A

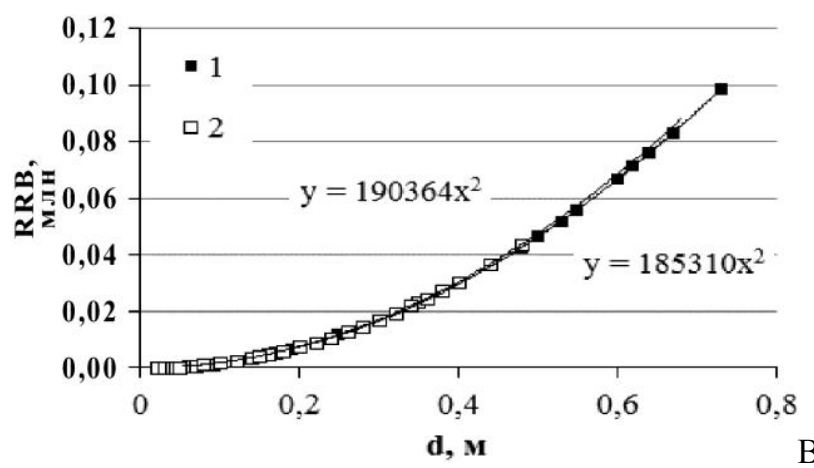

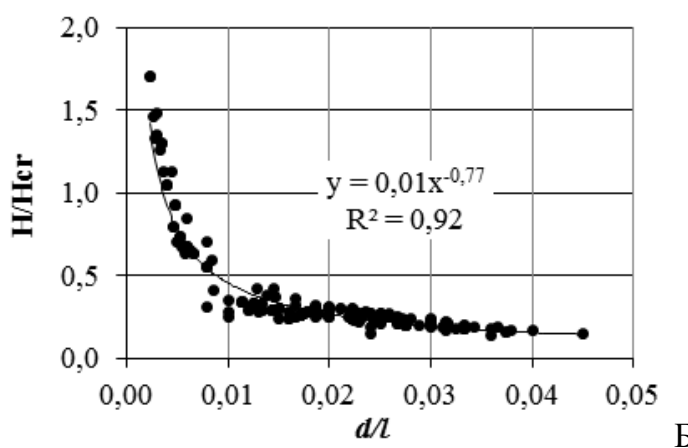

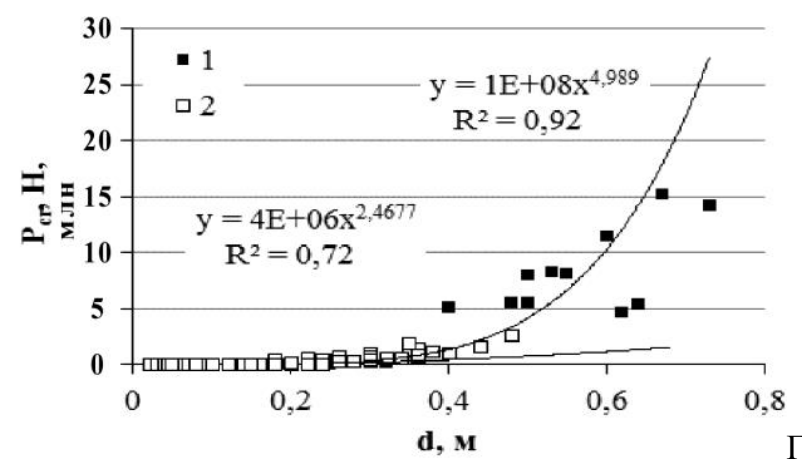

Рисунок 6 - Зависимость параметров механической устойчивости от морфологического маркера (d/I и d) для Acer platanoides L. в условиях города Донецка.

$A$ - зависимость жесткости на изгиб от отношения $\mathrm{d} /$; ;

5 - зависимость отношения высоты к критической высоте от отношения $\mathrm{d} / \mathrm{l}$;

$B$ - зависимость относительного сопротивления изгибу от диаметра ствола;

Г- зависимость предельно допустимой нагрузки от d/l.

1 - древесные растения произрастают в условиях дендрария Донецкого ботанического сада; 2 - древесные растения произрастают вдоль автомагистралей г. Донецка

\section{Список литературы:}

1. Савинцева Л.С. Экологический анализ адаптивных механизмов растений в урбанизированной среде: дис. ... канд. биол. наук. Киров, 2015. 169 с.

2. Ибрагимова Э.Э., Бандак И.В., Дрозд А.С. Флуктуирующая асимметрия листьев Morus alba L. как биоиндикатор аэротехногенного загрязнения урбоэкосистем // Ученые записки Таврического национального университета им. В.И. Вернадского. Серия «Биология, химия». 2011. Т. 24, № 2. С. 129-135.

3. Татарникова В.Ю., Дашиева О. Древесные растения и городская среда // Актуальные проблемы лесного комплекса. 2009. № 23. С. 191-194.

4. Виноградова Е.Н., Коршиков И.И. Генотипические особенности различающихся по устойчивости к эмиссиям автотранспорта деревьев Acer platanoides L. в насаждениях вдоль городской автомагистрали // Вестник Удмурдского университета. 2015. Т. 25, вып. 1. С. 7-12.

5. Коршиков И.И., Виноградова Е.Н. Изменение физиолого-биохимических показателей листьев различающихся по устойчивости к выхлопным газам деревьев Acer platanoides L. и Acer pseudoplatanus L. в насаждениях вдоль автомагистрали // Промышленная ботаника. 2005. Вып. 5. С. 75-84.

6. Токарева Т.Г., Леонтьев Р.В. Шумозащитные свойства древесных растений и их использование в озеленении // Электронный научно-образовательный журнал ВГСПУ «Грани познания». 2018. № 4. С. 63-66.

7. Васильев А.В. Проблемы оценки сочетания влияния шума и других физических факторов на здоровье человека // Известия Самарского научного центра Российской академии наук. 2012. Т. 14, № 6. C. $158-165$.

8. Голенков В.А. Комплексная оценка воздействия автотранспорта на акустическую среду городских территорий // Информационные технологии и инновации на транспорте: мат-лы междунар. науч.практ. конф. 19-20 мая 2015 г., г. Орел, Российская Федерация / отв. ред. А.Н. Новиков. Орел: ФГБОУ ВПО «Госуниверситет - УНПК», 2015. С. 168-178.

9. Мелькумов Г.М., Волков Д.Э. Флуктуирующая асимметрия листовых пластинок клена остролистного (Acer platanoides L.) как тест экологического состояния паркоценозов городской зоны // Вестник ВГУ. Серия: География. Геоэкология. 2014. № 3. С. 95-98.

10. Серебрякова Н.Е., Карасева М.А., Карасев В.Н., Медведкова Е.А. Устойчивость зеленых насаждений в условиях техногенного загрязнения города Нижнекамска // Вестник Поволжского государственного технологического университета. Серия: Лес. Экология. Природопользование. 2017. № 2 (34). С. 58-72.

11. Бухарина И.Л. Эколого-биологические особенности адаптации древесных и травянистых растений в условиях интенсивной техногенной нагрузки // Вестник МарГТУ. 2009. № 3. С. 84-90.

12. Николаевский В.С., Васина И.В., Николаевская Н.Г. Влияние некоторых факторов городской среды на состояние древесных пород // Лесной вестник. 1998. № 2. С. 28-38.

13. Жуков А.В., Штирц Ю.А., Жуков С.П. Оценка методами геометрической морфометрии морфологической изменчивости листовых пластинок Betula pendula Roth в экосистемах с различной степенью антропогенной трансформации // Проблеми екології 
та охорони природи техногенного регіону. 2011. № 1. C. $128-134$.

14. Корниенко В.О., Калаев В.Н. Механическая устойчивость древесных пород и рекомендации по предотвращению их аварийности в городских насаждениях / под ред. С.А. Приходько. Воронеж: Роза ветров, 2018. $92 \mathrm{c}$.

15. «Руководство по контролю загрязнения атмосферы. РД 52.04.186-89» (утв. Госкомгидрометом СССР 01.06.1989, Главным государственным санитарным врачом СССР 16.05.1989). 615 с.

16. ГОСТ 28168-89 Почвы. Отбор проб.
17. Савельева Л.С. Устойчивость деревьев и кустарников в защитных лесных насаждениях. М.: Лесная промышленность, 1975. 168 с.

18. Niklas K.J., Spatz H.C. Worldwide Correlations of Mechanical Properties and Green Wood Density // American Journal of Botany. 2010. Vol. 97 (10). P. 1587-1594.

19. Niklas K.J. Plant Biomechanics: an engineering approach to plant form and function // Chicago: University of Chicago Press, 1992. 607 p.

20. Лакин Г.Ф. Биометрия. М.: Высшая школа, 1990. $352 \mathrm{c}$

\title{
ACER PLATANOIDES L. IN THE CONDITIONS OF ANTHROPOGENIC LOAD OF DONETSK
} (C) 2019

\author{
Kornienko Vladimir Olegovich, senior lecturer of Biophysics Department \\ Kolchenko Olga Ruslanovna, master student of Biophysics Department \\ Donetsk National University (Donetsk, Donetsk People's Republic) \\ Matveeva Tatyana Borisovna, candidate of biological sciences, \\ associate professor of Chair of Biology, Ecology and Methods of Teaching \\ Samara State University of Social Sciences and Education (Samara, Russian Federation)
}

Abstract. This paper presents ecological and biological characteristics of holly maple (Acer platanoides L.) that hasn't been previously described in the conditions of Donetsk. The authors describe urban environment as a broeksema and transformation in it under the influence of anthropogenic factors. The paper considers the influence of the anthropogenic environment in the city on plant organisms, as well as physiological and morphological changes in them. In the course of the research, a high level of anthropogenic load in Donetsk was determined based on the analysis of vibration and acoustic noise along highways, concentration of heavy metals in soils and concentration of aeropolutants in the air in the study areas. A close relationship between the fluctuating asymmetry index of holly maple leaf plates and the viability index and the level of noise pollution along highways has been established. The authors have studied basic parameters of the mechanical resistance of Acer platanoides L. in Donetsk, in the conditions of technogenic contamination and control (arboretum of the Donetsk Botanical Garden). It is established that young trees (5-7 years old) and the ones that have a low viability score due to the approach of critical age in the conditions of the city are at the greatest risk of breakage. The results can be used in biomonitoring studies of the urban environment state.

Keywords: Acer platanoides L.; anthropogenic load; heavy metals; airpollutants; vibration and acoustic noise; mechanical stability; rigidity; fluctuating asymmetry; viability; Donetsk; Donetsk Botanical Garden; biomonitoring; bioindication; urban environment; woody plants.

$* * *$

УДК 574

DOI 10.24411/2309-4370-2019-13108

Статья поступила в редакцию 30.04.2019

\section{БИОЦЕНОТИЧЕСКИЕ КОМПЛЕКСЫ ОЗЁР И ЭСТУАРИЕВ ЮЖНОГО И ЦЕНТРАЛЬНОГО ПРИМОРЬЯ}

(C) 2019

Милованкин Павел Геннадьевич, научный сотрудник лаборатории прикладной биоценологии

Тихоокеанский филиал Всероссийского научно-исследовательского института

рыбного хозяйства и океанографии (г. Владивосток, Российская Федерация)

Аннотаичя. Проведённые в 2005-2013 гг. в тёплый период года (май - октябрь) исследования озёр и эстуариев центрального и южного Приморья позволили выделить различия между ними по составу уловов рыб и нектобентоса (крабов, креветок и шримсов). В соответствии с данными кластерного анализа, в исследованных водоёмах выделены 7 биоценотических комплексов: озёра юга Приморье и придаточная система p. Раздольной; реки Гладкая и Тесная; реки Рязановка, Барабашевка, устье реки Артёмовка и реки центрального Приморья; нижнее течение р. Раздольной, реки Артёмовка и Шкотовка, верхняя часть эстуария Суходола; основная часть эстуария Раздольной; эстуарий Суходола и мористая часть эстуариев центрального Приморья. Средняя удельная биомасса гидробионтов в озёрах и эстуариях южного и центрального Приморья со-

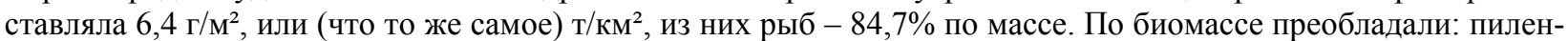
гас Planiliza haematocheila $(1,036)$, на втором месте молодь краснопёрки Tribolodon spp. $(0,904)$ и на третьем месте - японский мохнаторукий краб Eriocheir japonica $\left(0,606\right.$ г $\left./ \mathrm{M}^{2}\right)$. Во всех семи биоценотических комплексах отмечены Acanthogobius lactipes, шримсы Crangon spp., Gasterosteus nipponicus, Gymnogobius urotaenia, Palaemon spp., Pungitius sinensis, Tribolodon spp. и Tridentiger brevispinis. Всего выполнено 68 микросъёмок (700 ловов) в тёплый период года (май - октябрь), выявлено 106 таксонов рыб и нектобентоса. 